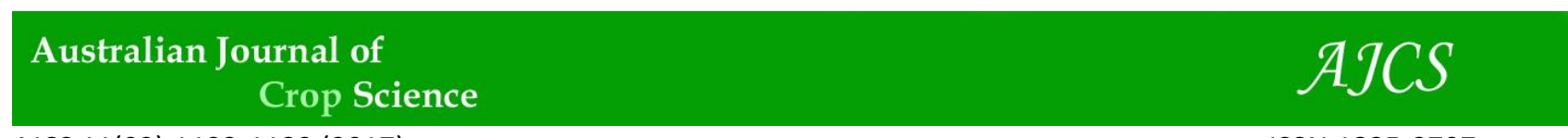

AJCS 11(09):1123-1129 (2017)

ISSN:1835-2707

doi: 10.21475/ajcs.17.11.09.pne536

\title{
Distribution of organic metabolites after Fusarium wilt incidence in tomato (Solanum lycopersicum L.)
}

\author{
Muhammed Alsamir ${ }^{1,2 *}$, Tariq Mahmood ${ }^{1}$, Nabil Ahmad ${ }^{1}$, Richard Trethowan ${ }^{1}$ \\ ${ }^{1}$ Plant Breeding Institute, Faculty of Agriculture and Environment, University of Sydney, Cobbitty, NSW 2570 , \\ Australia \\ ${ }^{2}$ The Date Palm Research Center, University of Basrah, Basrah, Iraq
}

*Corresponding author: alsamir.hameed@sydney.edu.au; malsamir@hotmail.com

\begin{abstract}
Tomato is an important vegetable crop worldwide and Fusarium wilt is a significant disease of tomato in many countries. One hundred and fifty three diverse tomato genotypes collected from local and exotic sources were screened for resistance to $F$. solani in the greenhouse. Significant variation in genotype response to inoculation was observed. The organic metabolite profiles of resistant and susceptible genotypes were assessed to determine the basis of resistance. Significant genetic variation was observed for ABA, malic acid, citric acid, fructose, glucose, sucrose, L-proline and myo-inositol. The disease treatment produced significant changes in fructose, glucose, proline and sucrose and significant genotype-by-treatment interaction was observed for ABA, citric acid, fructose, glucose, malic acid and sucrose, indicating that genetic improvement of these traits is feasible. Disease incidence was strongly associated with citric acid $\left(\mathrm{R}^{2}=0.84\right)$, sucrose $\left(\mathrm{R}^{2}=0.72\right)$ and $\mathrm{L}$-proline $\left(\mathrm{R}^{2}=0.76\right)$. Principal component analysis confirmed that citric acid and L-proline were important in determining plant disease response. Genetic variation for Fusarium wilt resistance can be used to develop new tomato cultivars with improved disease resistance.
\end{abstract}

Keywords: Genetic variation, Fusarium wilt, disease incidence, tomato germplasm, organic metabolites.

Abbreviations: ABA_Amino butyric acid; AVRDC_Asian vegetable research and development centre; Dis incidence_Disease incidence; DW loss_Dry weight loss; TGRC_Tomato genetics resource center; VRI, Pakistan_Vegetable Research Institute, Pakistan.

\section{Introduction}

Tomato (Solanum lycopersicum L.) is an important vegetable and cash crop globally. Tomato is an important source of vitamins and minerals and the use of tomato products continues to rise (Mirza, 2007) . However, fungal diseases affect tomato and the most important of these are the soil borne fungal pathogens including Fusarium spp., Rhizoctonia solani and Sclerotium rolfsii (El-Mohamedy et al., 2014; Abdel-Monaim, 2012 ; Saad 2006). These diseases commonly cause root rots and wilt. $F$. solani causes foot rot and can survive indefinitely as a saprophyte in organic matter (as chlamydoconidia) and is not transmitted via seed (de Guadalupe Moctezuma-Zárate et al., 2013). Foot rot of tomato was first reported in Australia in1975 (Vawdrey and Peterson, 1988) and was later observed in California in 1991 (Cucuzza et al., 1992). The disease was subsequently found in Brazil (Wolcan et al., 1994). A 2000-2001 survey reported that the disease was present in at least five counties (Yolo, Sutter, San Joaquin, Sacramento, and Stanislaus) in the Central Valley of California (Sagara, 2004). The pathogen also causes wilt and rot diseases on a wide range of other crops including stem and fruit rot of greenhouse pepper (Cerkauskas, 2001) and root and fruit rot of Cucurbita spp., root and stem rot of pea, sudden death syndrome of soybean, foot rot of bean and dry rot of potato tubers during storage (Zaccardelli et al., 2008).

The symptoms of Fusarium wilt begin as gradual yellowing and wilting of the lower leaves (Khan and Khan, 2002) in response to the inter-cellular growth of microconidia in the xylem of the stem and root. As a result, the infected xylem fails to meet water demand resulting in plant death (Burgess et al., 2008). Spores from the conidia are released into surrounding tissues as the plant dies and later form chlamydospores that fall back into the soil (Jones, 2000) . These spores can remain viable in the soil up to 30 years or until conditions are favorable for re-infection (Thangavelu et al., 2004). F. solani is distinguished from other Fusarium spp. by distinct morphological features (Leslie and Summerell, 2008). These include growth patterns in specific culture (Matuo and Snyder, 1973) and differing macroconidia size at different geographical locations (Leslie and Summerell 2008).

The control of soil borne pathogens is primarily managed by fungicide applications and grafting (El-Mougy et al., 2004). However, intensive application of fungicides is hazardous to human health and the environment and is therefore not always acceptable. Thus more sustainable approaches to the control of plant diseases are needed (Mandal et al., 2009).

Plants have evolved integrated disease defense mechanisms that include physical and chemical barriers, the production of anti-fungal compounds and stronger cell walls (Freeman and Beattie, 2008; Malinovsky et al., 2014; Yadeta and Thomma, 2013). These mechanisms offer an effective defense against infection. 
Plant defense against invading pathogens involves complex responses that culminate either in plant susceptibility or resistance. Virulent pathogens colonize the host plant by surpassing the plant resistance mechanism. Many pathogens have the ability to manipulate host gene expression to benefit their fitness causing infection in the host plant (SenthilKumar and Mysore, 2013).

In addition to preexisting disease defense barriers, plants can mobilize structural and chemical defense barriers that become active after pathogen attack. These inducible defense mechanisms are controlled by the innate plant immune system, which provides protection against the majority of the potentially harmful microorganisms. The plant immune system involves hormones such as salicylic acid (SA) and jasmonic acid. Plants can sensitize their immune system to respond to specific alarm signals in hostile conditions ( Conrath, 2011; Pastor et al., 2013).

Luna et al. (2014) reported that certain chemicals can enhance the plant immune system including b-aminobutyric acid (BABA), which elicits broad-spectrum disease protection. However, BABA also suppresses plant growth when applied in high doses.

Sugars have a regulatory function and influence all phases of the life cycle of plants, interact within phytohormones and control the processes of growth and development (Wind et al., 2010; Stokes et al., 2013). There are many reports of the importance of sugar levels in plant resistance to diseases caused by fungal pathogens and oomycetes, however their role as signal molecules in defense responses has only been described recently (Doehlemann et al., 2008; Moghaddam and Van den Ende, 2012).

Mandavia et al. (1990) and Rathod and Vakharia (2011) observed higher proline content in chickpeas under disease stress conditions. Similar responses were noted in cotton (Jiang et al., 2004). Proline can therefore be used as indicator of stress. Hassanein et al. (2016) and Gherbawy et al. (2012) reported that proline content significantly increased in wheat cultivars were infected with various Fusarium species. However, the relationship between Fusarium wilt ( $F$. solani) incidence and the distribution of organic metabolites in tomato is still elusive and requires more work. The resulting metabolite and gene information will allow identification and manipulation of traits that induce disease resistance.

The current study aimed to: i) assess genetic variability in tomato germplasm for resistance to Fusarium wilt caused by Fusarium solani, and ii) identify the organic metabolites that were important in regulating plant response to Fusarium wilt stress.

\section{Results}

\section{Pathogenecity test}

Significant genotypic differences in disease incidence and dry weight loss were observed (Supplementary Table 1). Differences between disease treatments (un-inoculated and inoculated) and significant genotype $(\mathrm{G}) \mathrm{x}$ treatment $(\mathrm{T})$ interactions were observed for both the traits (Table 1).

Twelve genotypes; Jaune Flamme, Amish Paste, Green Grape, Tai-1042, Early Wonder, LA 0373 (S. pimpinellifolium), LA 0716 (S. Pennellii), LA 1930 (S. chilense), VI006475, VI006476, VI005856 and VI007535 recorded a disease incidence of zero and were classified as tolerant. In contrast, fourteen genotypes including Iles Yellow Latvian, Bonita, Bush Beef Steak, Sasha Altai , Jagour, LA 3866, LA 4231, LA 4234, LA 4236, LA 4247, LA 4248, LA 4252, LA 3847 and VI006706 recorded a 100\% disease incidence and were classified as sensitive
(Supplementary Table 1).

The plant dry weight loss due to Fusarium wilt was lowest for LA 0373 (S. pimpinellifolium), LA 0716 (S. Pennellii), LA 3871, VI005856, LA 1930 (S. chilense), Early Wonder, Amish Paste and VI006475. The dry weight losses of these genotypes were less than $18 \%$ loss and differed significantly from other genotypes (Fig 1). Many genotypes suffered high dry weight loss and the differences among these materials were not significant (Fig 1).

\section{Organic metabolite analysis}

Significant differences were observed among genotypes for ABA levels (Table 1). However, no significant differences in ABA were observed between disease treatments although a significant $\mathrm{G} \times \mathrm{T}$ interaction was found. The highest ABA content was found in VI005856 and the lowest in LA1930.

Highly significant differences were observed among the genotypes for citric acid (Table 1). However, the disease treatment was not significant, although a significant $\mathrm{G} \times \mathrm{T}$ interaction was found. The highest citric acid content of $7.05 \mu \mathrm{g} / \mathrm{mL}$ was observed in LA4252 followed by LA3847 $(6.03 \mu \mathrm{g} / \mathrm{mL})$. The lowest concentration was found in VI005856 $(3.24 \mu \mathrm{g} / \mathrm{mL})$. Significant differences among genotypes and disease treatments were observed for fructose and a significant $\mathrm{G} \times \mathrm{T}$ interaction was found. The highest concentration of fructose was observed in VI005856 (Table 2). Significant differences among genotypes and disease treatments were observed for glucose and a significant $\mathrm{G} \times \mathrm{T}$ interaction was found (Table 1). Glucose levels were lower in the control than the disease treatment. The highest concentration was found in VI005856 $(6.03 \mu \mathrm{g} / \mathrm{mL})$ and LA1930 $(5.99 \mu \mathrm{g} / \mathrm{mL})$ (Table 2). Significant L-Proline differences were observed among genotypes and disease treatments (Table 1). However, no $\mathrm{G} \times \mathrm{T}$ interaction was observed. L-Proline was significantly higher under disease pressure (Table 2). Significant differences among genotypes were observed for malic acid content; however the disease treatment were non-significant (Table 1). Nevertheless, a significant $\mathrm{G} \times \mathrm{T}$ interaction was observed and the highest malic acid content was found in VI005856 and LA4252 (Table 2). Myo-inositol was highly significantly different among genotypes (Table 1). However, no significant differences between disease treatments were observed and no significant $G \times T$ interaction was found. The highest concentration of myo-inositol was found in LA0373 and VI005856 and the lowest concentration in Bush Beef Steak.

Sucrose was highly significantly different among genotypes and between disease treatments and a significant $G \times T$ interaction was observed (Table 1). Sucrose levels were significantly lower under disease pressure. The highest concentration was found in LA0373 $(28.95 \mu \mathrm{g} / \mathrm{mL})$ and LA1930 $(28.52 \mu \mathrm{g} / \mathrm{mL})$ and the lowest in Bush Beef Steak $(7.08 \mu \mathrm{g} / \mathrm{mL})$ (Table 2). The correlations among metabolic traits are presented in Table 3 . ABA content was significantly positively correlated with malic acid and myo-inositol positively correlated with L-Proline. Citric acid, sucrose content and L-Proline were all significantly positively correlated with disease incidence. Principal component analysis (PCA) (Fig 2) showed citric acid, L-proline, and myo-inositol to be important in determining disease incidence. PCA accounted for $99.89 \%$ of the total variance.

\section{Discussion}

Of the full set of one hundred and fifty three genotypes, twelve were categorized as tolerant to $F$. solani based on low 
Table 1. Analysis of variance for various traits with and without disease inoculation.

\begin{tabular}{|c|c|c|c|c|c|c|c|c|c|}
\hline TRAIT & $\mathrm{SOV}$ & DF & MS & Prob. & TRAIT & SOV & $\mathrm{DF}$ & MS & Prob. \\
\hline & Entry & 152 & 1130.40 & $<.001$ & \multirow{3}{*}{ Malic acid } & Entry & 4 & 17.17 & $<.001$ \\
\hline \multirow[t]{3}{*}{ Disease incidence } & Treat & - & - & - & & Treat & 1 & 2.89 & 0.06 \\
\hline & Entry.Treat & - & - & - & & Entry.Treat & 4 & 3.05 & 0.023 \\
\hline & Entry & 152 & 105.04 & $<.001$ & \multirow{3}{*}{ Citric acid } & Entry & 5 & 8.96 & $<.001$ \\
\hline \multirow[t]{3}{*}{ Dry weight } & Treat & - & - & - & & Treat & 1 & 2.00 & 0.13 \\
\hline & Entry.Treat & - & - & - & & Entry.Treat & 5 & 0.75 & $<.001$ \\
\hline & Entry & 5 & 4.15 & $<.001$ & \multirow{3}{*}{ Fructose } & Entry & 5 & 11.54 & 0.002 \\
\hline \multirow[t]{3}{*}{$\mathrm{ABA}$} & Treat & 1 & 1.21 & 0.122 & & Treat & 1 & 12.11 & 0.015 \\
\hline & Entry.Treat & 5 & 2.26 & 0.01 & & Entry.Treat & 5 & 12.12 & 0.002 \\
\hline & Entry & 5 & 1.50 & $<.001$ & \multirow{3}{*}{ Glucose } & Entry & 5 & 5.03 & 0.046 \\
\hline \multirow[t]{3}{*}{ L-proline } & Treat & 1 & 0.32 & 0.013 & & Treat & 1 & 18.91 & 0.005 \\
\hline & Entry.Treat & 5 & 0.04 & 0.433 & & Entry.Treat & 5 & 6.38 & 0.023 \\
\hline & Entry & 5 & 472.51 & $<.001$ & \multirow{3}{*}{ Myo inositol } & Entry & 5 & 8.58 & $<.001$ \\
\hline \multirow[t]{2}{*}{ Sucrose } & Treat & 1 & 2628.19 & 0.001 & & Treat & 1 & 0.05 & 0.817 \\
\hline & Entry.Treat & 5 & 140.76 & $<.001$ & & Entry.Treat & 5 & 0.91 & 0.417 \\
\hline
\end{tabular}

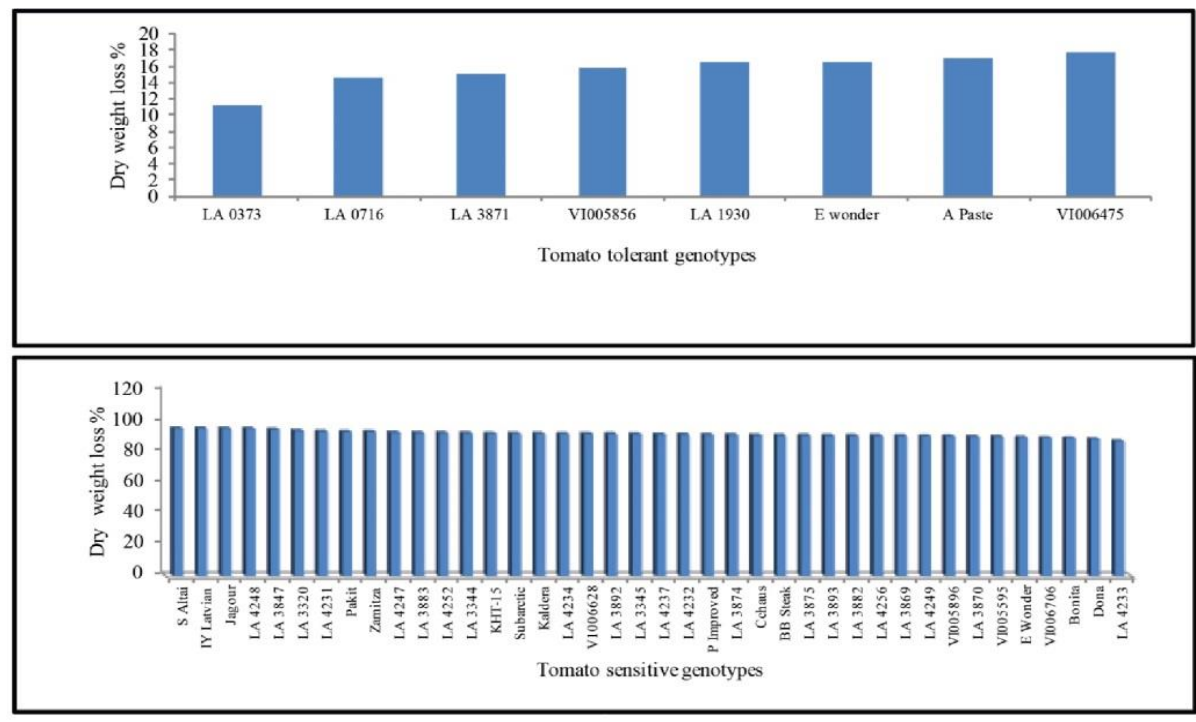

Fig 1. Dry weight loss $(\%)$ of different tomato genotypes to infection with $F$. solani $\left(\mathrm{LSD}_{0.05}=7.89\right)$.

Table 2. Genotypic means $(\mu \mathrm{g} / \mathrm{mL})$ for various organic metabolites.

\begin{tabular}{|c|c|c|c|c|c|c|c|c|c|}
\hline Metabolite & Treatment & LA 0373 & LA 1930 & VI005856 & LA 3847 & LA 4252 & BB Steak & Mean & LSD \\
\hline \multirow{2}{*}{$\mathrm{ABA}$} & Control & 1.62 & 1.69 & 3.32 & 3.07 & 5.56 & 1.38 & \multirow{2}{*}{2.55} & \multirow{2}{*}{1.02} \\
\hline & Disease stress & 1.69 & 1.56 & 3.86 & 2.07 & 2.37 & 2.39 & & \\
\hline \multirow{2}{*}{ Citric acid } & Control & 6.26 & 5.46 & 2.13 & 6.14 & 8.64 & 2.08 & \multirow{2}{*}{4.83} & \multirow{2}{*}{1.35} \\
\hline & Disease stress & 3.85 & 2.57 & 4.35 & 5.91 & 5.47 & 5.08 & & \\
\hline \multirow{2}{*}{ Fructose } & Control & 6.73 & 8.38 & 10.04 & 4.85 & 8.88 & 2.57 & \multirow{2}{*}{7.62} & \multirow{2}{*}{1.87} \\
\hline & Disease stress & 5.65 & 9.93 & 10.12 & 7.23 & 6.79 & 10.26 & & \\
\hline \multirow{2}{*}{ Glucose } & Control & 5.44 & 5.95 & 6.09 & 1.36 & 3.45 & 1.38 & \multirow{2}{*}{4.83} & \multirow{2}{*}{1.92} \\
\hline & Disease stress & 4.50 & 6.03 & 5.97 & 4.80 & 6.02 & 7.00 & & \\
\hline \multirow{2}{*}{ L proline } & Control & 2.25 & 1.77 & 2.01 & 1.15 & 1.17 & 1.00 & \multirow{2}{*}{1.67} & \multirow{2}{*}{0.29} \\
\hline & Disease stress & 2.75 & 1.98 & 2.43 & 1.22 & 1.33 & 1.02 & & \\
\hline \multirow{2}{*}{ Malic acid } & Control & 3.24 & 6.44 & 8.86 & - & 3.62 & 1.67 & \multirow{2}{*}{4.38} & \multirow{2}{*}{1.27} \\
\hline & Disease stress & 2.54 & 4.23 & 6.22 & - & 3.69 & 3.34 & & \\
\hline \multirow{2}{*}{ M inositol } & Control & 5.63 & 3.32 & 5.20 & 1.85 & 4.89 & 1.38 & \multirow{2}{*}{3.75} & \multirow{2}{*}{1.42} \\
\hline & Disease stress & 5.88 & 3.14 & 4.46 & 2.95 & 3.77 & 2.59 & & \\
\hline \multirow{2}{*}{ Sucrose } & Control & 42.84 & 47.88 & 21.91 & 11.05 & 24.71 & 7.08 & \multirow{2}{*}{15.45} & \multirow{2}{*}{5.22} \\
\hline & Disease stress & 15.05 & 9.15 & 1.56 & 1.17 & 2.16 & 0.79 & & \\
\hline
\end{tabular}




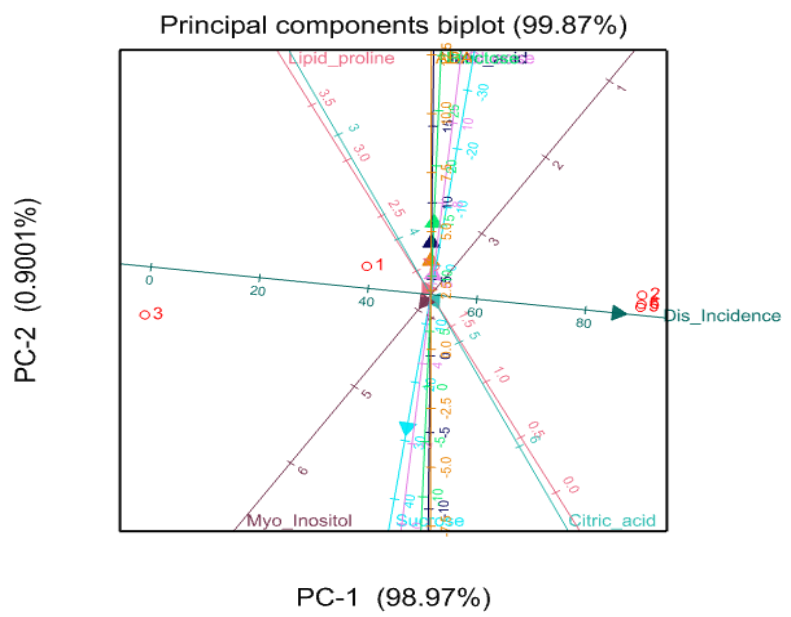

Fig 2. PC biplot showing organic metabolites response under disease stress condition.

Table 3. Correlations among various traits. The bold face values are significant at $\mathrm{P} \leq 0.05$.

\begin{tabular}{lcccccccc}
\hline Trait & ABA & Malic acid & Citric acid & Fructose & Glucose & Sucrose & L-proline & M Inositol \\
\hline ABA & & & & & & & & \\
Malic acid & $\mathbf{0 . 9 6}$ & & & & & & & \\
Citric acid & 0.27 & 0.00 & & & & & & \\
Fructose & 0.43 & 0.58 & -0.29 & & & & & \\
Glucose & 0.33 & 0.33 & -0.02 & 0.78 & & & & \\
Sucrose & -0.59 & -0.56 & -0.69 & -0.44 & -0.54 & & & \\
L-proline & 0.10 & 0.14 & -0.65 & -0.18 & -0.48 & 0.73 & & \\
Myo-Inositol & 0.07 & -0.07 & -0.28 & -0.56 & -0.60 & 0.69 & $\mathbf{0 . 8 7}$ & -0.60 \\
Dis Incidence & 0.26 & 0.08 & $\mathbf{0 . 9 2}$ & 0.01 & 0.34 & $\mathbf{- 0 . 8 5}$ & $\mathbf{- 0 . 8 7}$ & \\
\hline
\end{tabular}

disease incidence and relatively low dry weight loss under disease stress (Supplementary Table 1). However, some genotypes did not show high disease incidence but lost significant dry weight. Thus some genotypes lost energy in overcoming disease stress, even when no disease symptoms were apparent; a finding similar to Alwathnani and Perveen, (2012).

The Fusarium pathogen interrupts enzyme activity, especially those related to pathogenicity including cellulase, lipase, protease, pectinase and many others (de Guadalupe Moctezuma-Zárate et al., 2013). Changes in the activity of phenol-oxidizing enzymes also disrupt the metabolic pathways in damaged tissues (Mehrotra and Agarwal, 2003). The high virulence of $F$. solani on tomato genotypes in this study is similar to earlier reports of the devastating effects of Fusarium on tomato (Khan and Khan, 2002) and other species including potato, corn and lemon (Labrada et al., 2003; Manuel et al., 2003; Fasio et al., 2003).

The significant genetic variation for ABA, malic acid, citric acid, fructose, glucose, sucrose, L-proline, and myo-inositol observed in the current study and their association with plant response to disease stress can be used to breed new cultivars with improved metabolite profiles. Genotypes that maintain optimum levels of citric acid, sucrose and L-proline had better tolerance to disease than genotypes with lower levels. The positive and significant correlation between disease incidence and citric acid content supports this notion (Table 3 ). These results disagree with some earlier reports (Szopinska, 2013; Awadalla, 2008), but support Kamilova et al. (2006) who observed that Fusarium oxysporum f. sp. radicis-lycopersicum, the causal agent of foot and root rot in tomato, did not change the total amount of organic acid but instead decreased citric acid content. The significant $\mathrm{G} \times \mathrm{T}$ interaction for citric acid (Table 1) indicates that genetic improvement of this trait is possible in tomato. The significant negative correlation between disease incidence and sucrose content (Table 3) indicates that genotypes maintaining higher levels of sucrose under disease stress had greater tolerance to disease. Doehlemann et al., (2008) also reported a decrease in endogenous levels of sucrose and monosaccharides (glucose and fructose) following fungal infection in maize. High sugar levels enhance plant resistance in most fungal pathogen-plant systems. Sugars provide energy and structural material for defense in plants. Sugars enhance an oxidative burst at early stages of infection, thus increasing lignification of cell walls, stimulation of flavonoid synthesis and induction of certain PR proteins (Morkunas and Ratajczak, 2014). The significant $G \times 1$ interaction observed for sucrose content indicates that genetic improvement of this trait is feasible. The significant negative correlation between disease incidence and L-proline showed that higher L-proline reduced disease incidence. These results support earlier findings (Fabro et al., 2004). However, G x T interaction was not significant and this may limit the genetic improvement of L-proline content in tomato. Nevertheless, new diversity may be found that could provide a basis for genetic improvement.

The significant shoot dry weight loss of some highly susceptible genotypes in the current study can be attributed to vascular pathogenesis. The symptoms on tomato begin with gradual yellowing and subsequent wilting of the lower leaves (Khan and Khan, 2002) due to micro-conidial inter-cellular growth in the xylem of the stem and the root. The plant subsequently fails to meet water requirements under stress and ultimately dies (Burgess et al., 2008).

However, a significant number of genotypes showed tolerance to the pathogen. The tolerance response can be attributed to a variety of protective mechanisms, such as the induction of systemic acquired resistance (Kamal et al., 2008) and the accumulation of phenolic compounds. Southerton and 
Deverall (1990) reported that wheat varieties resistant to Puccinia recondita had accumulated phenolic compounds. Some physiological responses are regulated by $\mathrm{R}$ genes, which encode putative receptors that perceive the pathogen products expressed during pathogen infection. It is widely known that a single $\mathrm{R}$ gene provides resistance to one or more strains of a specific pathogen (Pink, 2002). The susceptible reaction of a number of tomato genotypes in the current study is likely attributed to lack of these resistance mechanisms. Diverse Fusarium pathotypes cause enormous damage to crops (O'Donnell, 2000; Chehri, 2014 ; Brasileiro et al., 2004 ; Thatcher et al., 2012). Genetic information on plant response to certain pathotypes is available for some species (Sperschneider et al., 2015); however such information on tomato response to $F$. solani is minimal. This study found significant genetic variation for tolerance to $F$. solani in tomato and identified several potential biochemical markers. However, the genetic control of this response remains unclear. The rate of genetic improvement of tomato disease resistance could be significantly increased if the genes governing tolerance are identified.

\section{Materials and methods}

\section{Plant materials}

The two factor greenhouse experiment comprised of 153 genotypes evaluated at two disease levels (non-inoculated and inoculated) with three replications. The genotypes included the wild species S. pimpinellifolium, S. Pennellii and S. chilense and 150 accessions of $S$. lycopersicum, including 11 heirloom varieties. Seeds of 43 accessions were obtained from the Tomato Genetic Resource Center (TGRC, UC Davis, USA), 56 accessions from the World Vegetable Center (AVRDC, Taiwan), 43 accessions from the Vegetable Research Institute (VRI, Faisalabad, Pakistan) and 11 heirloom varieties from the Diggers Club, Dromana, Victoria, Australia. The experiment was established in a micro-climate room within a larger greenhouse. The day/night room temperature was maintained at $27 / 22^{\circ} \mathrm{C}$, relative humidity (RH) at $60 \%$ and the photoperiod adjusted to $12 \mathrm{~h}$ day/night. The experiment was established in $10 \mathrm{~cm}$ diameter plots filled with a pasteurized potting mix. One plant was transplanted to each plot. Slow release commercial fertilizer was added before transplantation and the pots watered as required. The plants in both the control and the disease treatments were maintained identically with the exception of disease inoculation.

\section{Pathogenicity test}

A pure F. solani isolate (ID: BRIP 28072) was obtained from the Plant Pathology Herbarium - Biosecurity Queensland Australia. The isolate was tested for pathogenicity in a preliminary study of several contrasting genotypes at both the seedling and adult stages of development following the protocol of Ondrej et al., (2008). The isolate demonstrated strong virulence in the preliminary test and was therefore deemed suitable for the current experiment.

\section{Preparation of fungal inoculum}

The inoculum was prepared by culturing the $F$. solani isolate on potato dextrose agar (PDA) for 10 days in Petri dishes. The microconidial suspension of $F$. solani was prepared by pouring $1 \mathrm{ml}$ of sterile water in each Petri dish to loosen the spores from the medium. The inoculum was then scrapped with the aid of a sterilized spatula from the surface of the Petri dishes and $1 \mathrm{ml}$ of growth suspension made up to $20 \mathrm{ml}$ in sterile bottles. The bottles were thoroughly shaken in a rotary shaker to dislodge the spores from the fungal mycelia to produce a concentration of $10^{9}$ spores $/ \mathrm{ml}$. The spore concentration was subsequently adjusted to the required concentration of $10^{6}$ spores / $\mathrm{ml}$ (Adebayo and Ekpo, 2004).

\section{Inoculation procedure}

Tomato seedlings were inoculated at the two-leaf stage by dipping the roots of each plant in either a freshly prepared spore suspension or water for the control treatment for $1 \mathrm{~min}$ followed by immediate replanting. Seedlings were maintained at $27^{\circ} \mathrm{C}$ under $12 \mathrm{~h}$ of light per day for up to five weeks (Jones et al., 1992).

\section{Disease scoring and plant sensitivity}

Disease incidence was recorded five weeks post-inoculation using the formula of Haruna et al. (2012):

Disease Incidence \%

$$
\begin{aligned}
& =\frac{\text { Number of wilting branches }}{\text { Number of total branches }} \\
& \times 100
\end{aligned}
$$

Dry weight loss was estimated using the formula:

Weight loss \%

Plant weight control - Plant weight disease treatment

$=\frac{\text { Plant weight control }}{}$

$\times 100$

\section{Organic metabolite analysis}

A subset of genotypes was selected for organic metabolite analysis based on disease reaction. The subset comprised six genotypes with two replications. Three genotypes with the lowest disease incidence score and low dry weight loss and three genotypes with the highest score and high weight loss were evaluated for organic metabolites under Fusarium wilt stress conditions. The metabolites included ABA (Aminobutyric acid), malic acid, citric acid, fructose, glucose, sucrose, L-proline, and myo-inositol. The Methanol/Chloroform/Water (MCW) method given below was used to extract organic metabolites.

\section{Methanol/Chloroform/Water (MCW) Extraction Method}

$40 \mathrm{mg}$ of freeze-dried tissue was weighed into a $2 \mathrm{ml}$ Eppendorf tube (screw cap) and $1 \mathrm{ml} \mathrm{MCW} \mathrm{(12:5:3)} \mathrm{was}$ added and the mixture incubated at $75^{\circ} \mathrm{C}$ for $30 \mathrm{~min}$, agitating from time to time. Water was used as the internal standard $(0.4 \mathrm{~g}$ of both penta-erythritol and xylitol dissolved in $100 \mathrm{ml} \mathrm{MQ}$ water). The mixture was centrifuged and 800 $\mu \mathrm{l}$ of supernatant was decanted into a clean Eppendorf tube. $500 \mu \mathrm{l}$ of MQ water and $200 \mu \mathrm{l}$ chloroform were added and mixed thoroughly with a vortex mixer, centrifuged and let stand for $10 \mathrm{~min} .700 \mu \mathrm{l}$ of the alcohol/aqueous phase (top) was removed and placed in a clean, round bottom Eppendorf tube already filled with $400 \mu 1$ of dry mixed bed resin. The tube was shaken for $2 \mathrm{hrs}$, then centrifuged and $400 \mu \mathrm{l}$ decanted into a clean Eppendorf tube. Samples were frozen and subsamples for derivatisation were placed into GC vials and dried (Merchant et al., 2006).

\section{Gas Chromatography Analysis}

Following extraction, the samples were analysed immediately 
using gas chromatography coupled with a triple quadruple mass spectrometer (GC-QQQ, Agilent Technologies, Santa Clara CA) as per Merchant et al. (2006). Fifty microliters of the extract were dried and re-suspended in $400 \mu \mathrm{L}$ anhydrous pyridine to which $50 \mu \mathrm{L}$ of trimethylchlorosilane (TMCS)/bis-trimethylsilyl-trifluoroacetamide mix (1:10, Sigma Aldrich, St Louis, MO) was added. Samples were incubated for $1 \mathrm{~h}$ at $75^{\circ} \mathrm{C}$ and analysed by gas chromatography within $12 \mathrm{~h}$. Separation of soluble carbohydrates and sugar alcohols was performed using an Agilent 7890A gas chromatograph (Agilent Technologies, Santa Clara, CA, USA) with a HP5 column ( $0.25 \mathrm{~mm}$ i.d., 30 $\mathrm{m}, 0.25 \mathrm{~mm}$ film thickness; Agilent Technologies, Santa Clara, CA, USA). Split injection was made at $300^{\circ} \mathrm{C}$ with an initial oven temperature program of $60^{\circ} \mathrm{C}$ for $2 \mathrm{~min}$, ramping up to $300^{\circ} \mathrm{C}$ at a rate of $10^{\circ} \mathrm{C} \mathrm{min}{ }^{-1}$ and maintained for 10 min. Column flow rate was maintained at $1.5 \mathrm{~mL} \mathrm{~min}^{-1}$. Peak integration was determined using Agilent Mass Hunter Workstation software (Agilent Technologies, Santa Clara, CA, USA).

\section{Statistical analyses}

All the data were normalized using standard deviation and analysis of variance conducted using a fixed effect model (GenStat v 18.0 statistical software package). The analysis was performed for both the large 153 genotype dataset and the smaller six genotype organic metabolite experiment. Differences were considered significant at $\mathrm{P}<0.05$. The principal component analysis (PCA) was conducted on the smaller data set using the same software.

\section{Conclusion}

The current study showed that significant genetic variation for resistance to Fusarium wilt existed in the germplasm assessed. The lines identified as tolerant to Fusarium wilt were geographically diverse, originating from Australia, Taiwan, Pakistan and the USA. It seems reasonable to conclude that sources of resistance to Fusarium wilt stress in tomato spread across continents and are different from each other. Clearly, suitable germplasm for each particular environment can be identified for resistance breeding. Variation in the expression of organic metabolites was helpful in classifying the disease reaction of the materials. Genotypes with high sucrose and L-proline content tended to have lower disease incidence. A significant $\mathrm{G} \times \mathrm{T}$ interaction for sucrose content indicated that this trait is amenable to genetic manipulation to improve disease resistance in tomatoes.

\section{Acknowledgments}

Authors acknowledge the contributions made by the staff and students of the Plant Breeding Institute, The University of Sydney for their help during these studies. Authors also thankfully acknowledge the contributions made by TGRC, and UC Davis for providing the tomato germplasm, Plant Pathology Herbarium - Biosecurity Queensland, Department of Agriculture, Fisheries, and Forestry for providing the fungal isolate, and ACIAR vegetables project HORT/2012/002 for supporting the heat stress research on tomatoes.

\section{References}

Abdel-Monaim M (2012) Induced systemic resistance in tomato plants against Fusarium wilt diseases. Int Res J.Microbiol. 3: 14-23.

Adebayo O, Ekpo E (2004) Effeciency of fungal and bacterial biocontrol organisms for the control of fusarium wilt of tomato. Nigerian Jof Hort Sci. 9:63-68.

Alwathnani HA, Perveen K (2012) Biological control of fusarium wilt of tomato by antagonist fungi and cyanobacteria. Afr J Biotech. 11: 1100-1105.

Awadalla OA (2008) Induction of systemic acquired resistance in tomato plants against early blight disease. The Egyptian J Exp Bio (Botany). 4: 53-59.

Brasileiro BTRV, Coimbra MRM, Morais Jr MAd, Oliveira NTd (2004) Genetic variability within Fusarium solani specie as revealed by PCR-fingerprinting based on PCR markers. Braz J Microbiol. 35: 205-210.

Burgess LW, Knight T, Tesoriero L, Phan HT (2008) Diagnostic manual for plant diseases in Vietnam. ACIAR Monograph. 129.

Cerkauskas RF, Brown J (2001) Bacterial stem and peduncle canker of greenhouse pepper. Can J Plant Pathol. 23(3):300-6.

Chehri K (2014) Molecular phylogeny of the Fusarium solani species complex (FSSC) isolated from soils in Iran. Botany. 92: 815-820.

Conrath U (2011) Molecular aspects of defence priming. Trends Plant Sci. 16: 524-531.

Cucuzza J, Watterson J, Bernhardt E (1992) Foot rot of tomato caused by Fusarium solani in California. Plant Dis. 76: 101.

de Guadalupe Moctezuma-Zárate M, Vargas-Morales JM, Cárdenas-González JF, Martínez-Juárez VM, AcostaRodríguez I (2013) Induction of Extracellular Lytic Enzymes by Fusarium solani. Adv Microbiol. 3: 24-30.

Doehlemann G, Wahl R (2008) Reprogramming a maize plant: transcriptional and metabolic changes induced by the fungal biotroph Ustilago maydis. Plant J. 56: 181-195.

El-Mohamedy RS, Jabnoun-Khiareddine H, Daami-Remadi M (2014) Control of root rot diseases of tomato plants caused by Fusarium solani, Rhizoctonia solani and Sclerotium rolfsii using different chemical plant resistance inducers. Tunis J Plant Prot. 9: 45-55.

El-Mougy NS, Abd-El-Kareem F, El-Gamal NG, Fatooh Y (2004) Application of fungicides alternatives for controlling cowpea root rot diseases under greenhouse and field conditions. Egypt J Phytopathol. 32: 23-35.

Fabro G, Kovács I, Pavet V, Szabados L, Alvarez ME (2004) Proline accumulation and AtP5CS2 gene activation are induced by plant-pathogen incompatible interactions in Arabidopsis. MPMI. 17: 343-350.

Fasio JAC, Rodríguez TdJM, Estrada RSG, Ortega JEC, Zequera IM, Barajas AJS (2003) Razas de Fusarium oxysporum $f$. sp. lycopersici Snyder y Hansen, en tomate (Lycopersicon esculentum Mill.) en el Valle de Culiacán, Sinaloa, México. Rev Mex Fitopatol. 21: 123-127.

Gherbawy YA, El-Tayeb MA, Maghraby TA, Shebany YM, El-Deeb BA (2012) Response of antioxidant enzymes and some metabolic activities in wheat to Fusarium spp. Infections. Acta Agro Hun. 60(4): 319-333.

Haruna S, Adebitan S, Gurama A (2012) Field evaluation of compost extracts for suppression of Fusarium wilt of tomato caused by Fusarium oxysporum f. sp. lycopersici. Int J Agr Res. 2(4). 
Hassanein RA, Hashem HA, Fahmy AH, Ibrahim AS, El Shihy OM, Qaid EA (2016) Protection Against Fusarium Head Blight: Important Defense Mechanisms Studied in Three Regenerated Egyptian Wheat Cultivars. J Stress Physiol Biochem. 12(3):18-43.

Jiang Y, Fang W, Zhu S, Ji D (2004) Relationship of verticillium wilt resistance with plant anatomical structure and biochemical metabolism in upland cotton. Zuo Wu Xue Bao. 31: 337-341.

Jones DR (2000) 'Diseases of banana, abaca and enset.' (CABI publishing). ISBN. 0851993559, 9780851993553.

Jones JP, Woltz S, Scott J (1992) Screening for resistance to Fusarium crown rot of tomato. In 'Proc. Fla. State Hort Soc. pp. 345-347.

Kamal A, Mohamed HM, Aly AA, Mohamed HA (2008) Enhanced onion resistance against stemphylium leaf blight disease, caused by Stemphylium vesicarium, by dipotassium phosphate and benzothiadiazole treatments. Plant Pathol J. 24: 171-177.

Kamilova F, Kravchenko LV, Shaposhnikov AI, Makarova N, Lugtenberg B (2006) Effects of the tomato pathogen Fusarium oxysporum f. sp. radicis-lycopersici and of the biocontrol bacterium Pseudomonas fluorescens WCS365 on the composition of organic acids and sugars in tomato root exudate. Mol Plant Microbe In. 19: 1121-1126.

Khan MR, Khan SM (2002) Effects of root-dip treatment with certain phosphate solubilizing microorganisms on the fusarial wilt of tomato. Bioresource Technol. 85: 213-215.

Labrada BG, Pérez NM, Ramírez JSP (2003) Hongos asociados a la semilla de frijol (Phaseolus vulgaris L.) en Aguascalientes, México. Rev Mex de Fitopatol. 21: 375378.

Leslie JF, Summerell BA (2008) 'The Fusarium laboratory manual.' (John Wiley \& Sons).

Luna E, Van Hulten M, et al. (2014) Plant perception of $\beta$ aminobutyric acid is mediated by an aspartyl-tRNA synthetase. Nat Chem Biol. 10: 450-456.

Mandal S, Mallick N, Mitra A (2009) Salicylic acid-induced resistance to Fusarium oxysporum f. sp. lycopersici in tomato. Plant Physiol Bioch. 47: 642-649.

Mandavia M, Bhalani P, Parameswaran M (1990) Biochemical studies on disease resistance in chickpea (Cicer arietinum) varieties resistant and susceptible to wilt disease (Fusarium oxysporum). Indian J Agric Chem. 3: 57-62.

Manuel BVC, Alejandro MJO, Hilda MGR (2003) Contaminación con hongos en maíz recién cosechado en el estado de Guanajuato durante el año. Instituto de Ciencias Agrícolas de la Universidad de Guanajuato. Unidad de Estudios Superiores de Salvatierra de la Universidad de Guanajuato.

Matuo T, Snyder WC (1973) Use of morphology and mating populations in the identification of formae speciales in Fusarium solani. Phytopathology. 63: 562-565.

Mehrotra R, Agarwal A (2003) Plant Pathology 2nd edi. In. ' (Tata Mc Graw Hill Publishing com. Ltd).

Merchant A, Richter A, Popp M, Adams M (2006) Targeted metabolite profiling provides a functional link among eucalypt taxonomy, physiology and evolution. Photochem. 67: 402-408.

Mirza I (2007) Tomato paste plant to be set up at Killa Saifullah. Retrieved on 5.05. 2017 at : http://www.pakissan.com/english/news/newsDetail.php?ne wsid $=15041$
Moghaddam MRB, Van den Ende W (2012) Sugars and plant innate immunity. J Exp Bot Ers.129.

Morkunas I, Ratajczak L (2014) The role of sugar signaling in plant defense responses against fungal pathogens. Acta Physiol Plant. 36: 1607-1619.

O'Donnell K (2000) Molecular phylogeny of the Nectria haematococca-Fusarium solani species complex. Mycologia. 919-938.

Ondrej M, Agritec S, Dostalova R, Agritec S, Trojan R (2008) Evaluation of virulence of Fusarium solani isolates on pea. Plant Protect Sci. 44(1): 9-18.

Pastor V, Luna E, Mauch-Mani B, Ton J, Flors V (2013) Primed plants do not forget. Environ Exp Bot. 94: 46-56.

Pink DA (2002) Strategies using genes for non-durable disease resistance. Euphytica. 124: 227-236.

Rathod P, Vakharia D (2011) Biochemical changes in chickpea caused by Fusarium oxysporium f. sp ciceri. Int J Plant Physiol Biochem. 3: 195-204.

Saad M (2006) Destruction of Rhizoctonia solani and Phytophthora capsici causing tomato root-rot by Pseudomonas fluorescens lytic enzymes. Res J Agric Biol Sci. 2: 274-281.

Sagara DD (2004) 'Characteristics of Foot Rot Caused by Fusarium Solani on Processing Tomatoes in California.'

Senthil-Kumar M, Mysore KS (2013) Nonhost resistance against bacterial pathogens: retrospectives and prospects. Annu Rev Phytopathol. 51: 407-427.

Southerton S, Deverall B (1990) Changes in phenolic acid levels in wheat leaves expressing resistance to Puccinia recondita f. sp. tritici. Physiol Mol Plant P. 37: 437-450.

Sperschneider J, Gardiner DM, Thatcher LF, Lyons R, Singh KB, Manners JM, Taylor JM (2015) Genome-wide analysis in three Fusarium pathogens identifies rapidly evolving chromosomes and genes associated with pathogenicity. Genome Biol Evol. 7: 1613-1627.

Stokes ME, Chattopadhyay A, Wilkins O, Nambara E, Campbell MM (2013) Interplay between sucrose and folate modulates auxin signaling in Arabidopsis. Plant Physiol. 162: $1552-1565$.

Szopinska D (2013) The effects of organic acids treatment on germination, vigour and health of zinnia (Zinnia elegans Jacq.) seeds. Acta Sci Pol Hortorum Cultus. 12.

Thangavelu R, Palaniswami A, Velazhahan R (2004) Mass production of Trichoderma harzianum for managing fusarium wilt of banana. Agric Ecosyst Environ. 103: 259263

Thatcher LF, Gardiner DM, Kazan K, Manners JM (2012) A highly conserved effector in Fusarium oxysporum is required for full virulence on Arabidopsis. Mol Plant Microbe. 25: 180-190.

Vawdrey L, Peterson R (1988) Fusarium solani, the cause of foot rot of tomatoes in Central Queensland. Australas Plant Pathol. 17: 24-25.

Wind J, Smeekens S, Hanson J (2010) Sucrose: metabolite and signaling molecule. Phytochemistry. 71: 1610-1614.

Wolcan S, Lori G, Ronco B (1994) Tomato foot rot (Fusarium solani). Evaluation parameters and inoculation techniques. Fitopatol Bras (Brazil).

Yadeta KA, Thomma BP (2013) The xylem as battleground for plant hosts and vascular wilt pathogens. Front Plant Sci. 4: $1-12$.

Zaccardelli M, Vitale S, Luongo L, Merighi M, Corazza L (2008) Morphological and molecular characterization of Fusarium solani isolates. J Phytopathol. 156(9):534-41. 